\title{
Simulation of Development of the Solid State Chain Reaction
}

\author{
Marina V. Ananyeva and Alexander V. Kalenskii* \\ Kemerovo State University \\ 6 Krasnaya Str., Kemerovo, 650043, Russia
}

Received 12.03.2015, received in revised form 21.04.2015, accepted 09.06.2015

In this work simulation of the kinetics of the explosive decomposition process in silver azide crystals was done. The non local behavior of the chain propagation stage was taken into account. The finite sizes of the sample and the laser radius, the energy transfer through the lattice, which causes the reagents' redistribution, were also taken into account. Optimal area of the crystal for the reaction to develop is the centre of the radiation zone.

Keywords: simulation, difference scheme, model of the chain reaction, explosive decomposition, energy transfer, energetic materials, silver azide.

\section{Моделирование развития твердофазной цепной реакции}

\author{
М.В. Ананьева, А.В. Каленский \\ Кемеровский государственный университет \\ Россия, 650043, Кемерово, ул. Красная, 6
}

Работа посвящена моделированию кинетики процесса взрывного разложения кристаллов азида серебра при нелокальном характере стадии развития цеепи. Моделирование процесса учитывает конечные размеры образиа, радиус инициирующего импульса, перенос энергии химической реакции по кристаллической решетке, который приводит к перераспределению кониентраций реагентов в кристалле. Оптимальной областью для развития твердофазной цепной реакции является центр облучаемой области.

(C) Siberian Federal University. All rights reserved

* Corresponding author E-mail address: kriger@kemsu.ru 
Ключевые слова: математическое моделирование, разностная схема, модель иепной реакции, взрывное разложение, перенос энергии, энергетические материалы, азид серебра.

\section{Introduction}

The main purpose of the simulation of the physical and chemical processes is the simultaneous examination of the chemical transformations and the physical processes, among these the main are the diffusion of the reagents and energy transfer [1,2]. Determination of the mechanisms of the initiation, propagation and development of the energetic materials' explosive decomposition has a wide applied meaning, as long as the inadvertent occurrence of the equipment based on the explosives causes significant material damage [3, 4]. The importance of the study lies in the necessity of development of the optical detonators [5] based on the initiating and high [6,7] explosives. There are two ways to describe the explosive decomposition process - thermal [8] and chain model [9]. In terms of the thermal model it is supposed that the material decomposes according to the one-stage reaction [10], the constant of this stage has the Arrhenius dependence on the temperature. In terms of the chain model the self accelerated mode is due to the reagent multiplication [11]. A lot of the experimental data on the silver azide explosive decomposition, initiated by the Nd:Yag laser, were explained in terms of the chain model. The aim of this work is to simulate the kinetics of generation, propagation of the reaction taking into account non-local behavior of the propagation stage and the finite radius of the initiating pulse, phenomenological model of the process that was proposed [12].

\section{Explosive decomposition model of the silver azide}

According to the phenomenological model of the silver azide's explosive decomposition the energy of the chain reaction might transfer along the crystal lattice and causes the e-h pairs' generation. The intensity of the reagents' generation is maximal in immediate vicinity of the reaction area and then decreases exponentially [13]:

$$
2 h \longrightarrow \mathrm{k}_{2}^{2+} \longrightarrow \mathrm{k}_{1} \longrightarrow 3 \mathrm{~N}_{2}+2 h+(h+e) \cdot \exp \left(-|\Delta x| / r_{0}\right),
$$

where $k_{1}$ - constant of the decomposition of $\mathrm{N}_{6}$-complex, $k_{1}$ - constant of $\mathrm{N}_{6}$-complex generation. Propagation stage is the interaction of two radicals $N_{3}{ }^{0}(h)$, localized in neighbor points of lattice. The constant of the reaction of $\mathrm{N}_{6}$ formation was estimated taking into account Coulomb repulsion, Debye screening and tunneling, and its value was equal to $k_{2}=0.5 \cdot 10^{-11} \mathrm{~cm}^{-3} \mathrm{~s}^{-1}[14]$. $\mathrm{N}_{6}$-complex decomposes with molecular nitrogen formation $\left(\mathrm{N}_{2}\right)$; the stage constant is $k_{1}=3 \cdot 10^{7} \mathrm{~s}^{-1}$ [15]. Released energy is accumulated by the electron and vibrational degrees of freedom of the nitrogen molecule. In terms of the model of the dipole interaction with the electron system of the crystal the constants of deactivation were estimated for the cases of e-h pairs' formation $\left(k_{e} \sim 10^{9} \mathrm{~s}^{-1}\right)$ and energy transfer to a band hole $\left(k_{v} \sim 10^{-12} \mathrm{~cm}^{3} \mathrm{~s}^{-1}\right)$ [15]. Deactivation of the nitrogen molecules causes the active particles generation propagation stage takes place not only in the reaction area, but also outside it with probability $\sim \exp \left(-x / r_{0}\right) . r_{0}$ was calculated using the experimental data $50 \pm 10 \mu \mathrm{m}$ [16]. Intensity of the generation stage depended on the illumination inside the sample [17], and was not taken into account in the context of the work.

Simulation of the process of the energy transfer was made taking into account the real geometry of the sample - in cylindrical coordinate system using the difference scheme [18]. For the calculations 


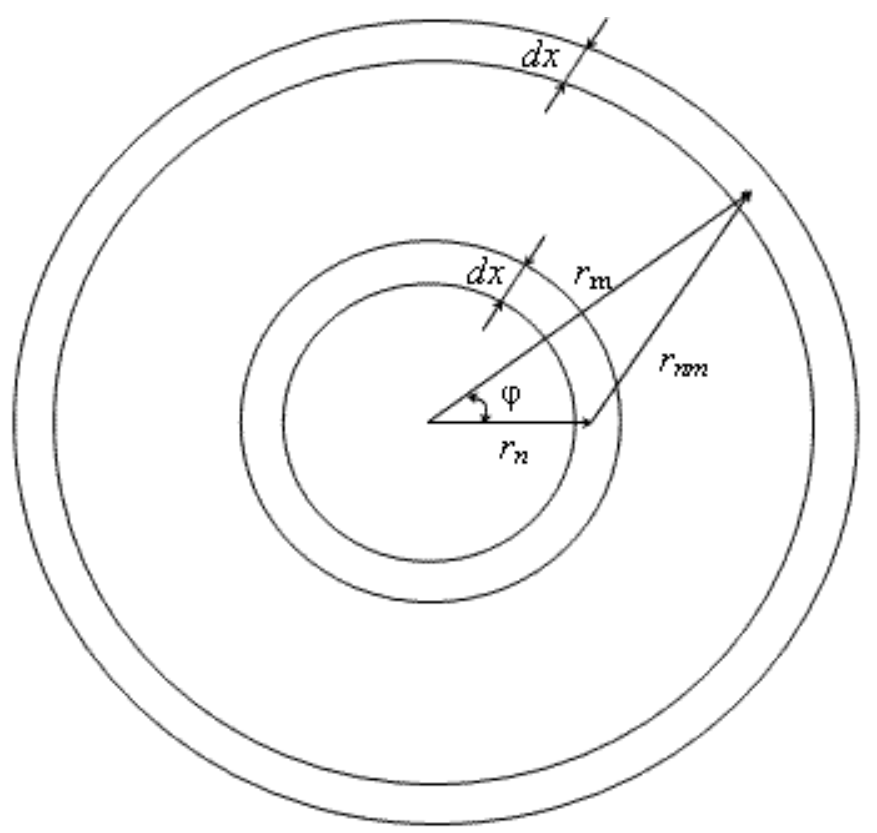

Fig. 1. Layout view of the reaction area in a cylindrical coordinates to estimate the efficiency of the reagents' generation in cell $n$ due to the reaction in cell $m$

the sample was divided into kn cells with the same cross dimensions $\mathrm{dx}$ (Fig. 1). The reaction in cell $\mathrm{n}$ influences the speed of generation of the active particles (chain carriers) in all cells of the crystal, mathematically this might be described as an action of the functional on the function of concentration. In this work the functional was taken in form of square matrix $k_{n} \cdot k_{n}$. The elements of the matrix, which relate the intensity of the chain carriers' generation in cell $\mathrm{n}$ with the speed of the chemical reaction in cell $m\left(\mathrm{~S}_{\mathrm{nm}}\right)$, were calculated by using the following procedure. The following conventional signs were used: $Y_{n}$ - number of holes in cell $n, A$ - concentration of $\mathrm{N}_{6}$ complex, $S_{n}-$ area of cell $n$. Let us estimate how the reaction speed in cell $n$ influence the reaction speed in cell $m$. The distance between cells $n$ and $m$ might be calculated as:

$$
\begin{gathered}
r_{m n}=\sqrt{r_{m}^{2}+r_{n}^{2}-2 r_{m} r_{n} \cos \varphi}, \\
r_{n}=d r\left(n-\frac{1}{2}\right) \quad r_{m}=d r\left(m-\frac{1}{2}\right)
\end{gathered}
$$

Speed of chain carriers' generation in any cell $n$ because of the reaction of $\mathrm{N}_{6}$ decomposition in cell $m$ might be calculated using the following expression:

$$
S_{n m}=T_{m} x_{n m},
$$

where $x_{n m}$-speed of the chain carriers' generation in cell $n$ due to the reaction in cell $m, T_{m}$-normalizing factor.

While the distance from the reaction area increases the energy decreases inversely as the square of the distance, and it decreases in $e$ times while the distance is equal to $r_{0}$ because of the absorption. 
The entire cylindrical segment with radius $r_{n}$ contains $A_{n} r_{n} d x d \varphi$ particles, so the number of particles generated in cell $m$ :

$$
Y_{m m}=\frac{A_{n} e^{-\frac{r_{m n}}{r_{0}}}}{2 \pi r_{0} r_{n m}} d x r_{n} d \varphi
$$

where $Y_{m n}$ is quantity of the chain carriers, generated in cell $m$ per unit time due to the reaction in cell $n$. For the layer containing cell $\mathrm{m}$ :

$$
\begin{gathered}
x_{n m}=2 \int_{0}^{\pi} d Y_{m \dot{o}} d \varphi, \\
S_{n m}=2 T_{m} \int_{0}^{\pi} \frac{e^{-\frac{r_{m n}}{r_{0}}} Y_{m n}}{2 \pi r_{0} r_{m n}} d \varphi .
\end{gathered}
$$

While $n=m$ value of $S_{n m}$ becomes infinite, what is why the piecewise function was used:

$$
f= \begin{cases}f_{1}(m), & m \subset[1, n-1] \cup\left[n+1, k_{n}\right] \\ f_{2}(m), & n=m\end{cases}
$$

According to the model the total value of the chain carriers, generated in cell $n$ because of the reaction in cell $m$, equal to $Y_{m n}$, i.e. one act of transformation generates one e-h pair. Coefficient $T_{m}$ was estimated using the following normalization:

$$
T_{m}=\frac{r_{m}}{\sum r_{n} \int_{0}^{\pi} \frac{e^{-\frac{r_{m n}}{r_{0}}} \beta_{n}}{2 \pi r_{0} r_{m n}} d \varphi}
$$

Concentration of the chain carriers generated in cell $m$ :

$$
p_{n m}=\frac{B_{n m}}{S_{m}}=\frac{2 \int_{0}^{\pi} d B_{n m} d \varphi}{2 \pi r_{m} d r}
$$

Calculation of matrix $S_{m n}$ was done in a spatial program, calculation of its components preceded the solution of the equation set, describing the kinetics of the decomposition process. $S_{n m}$ is square $\left(k_{n} \times k_{n}\right)$ matrix. Fig. 2 and 3 show the section of the matrix for the different values of $n\left(n_{l}=100\right.$ and $n_{2}=25$ ). Maximal value of the $y$-coordinate corresponds to the cell, along which the section was made. It is obvious that the diagonal elements have the maximal values, as long as these elements correspond to the probability of e-h pairs' generation in the same cell where the reaction takes place.

Asymmetry of the elements of matrix $S_{n m}$ is explained by the fact that the recombination of the reagents in the neighborhood of the surface is faster than in the crystal bulk. If the considering cell is 


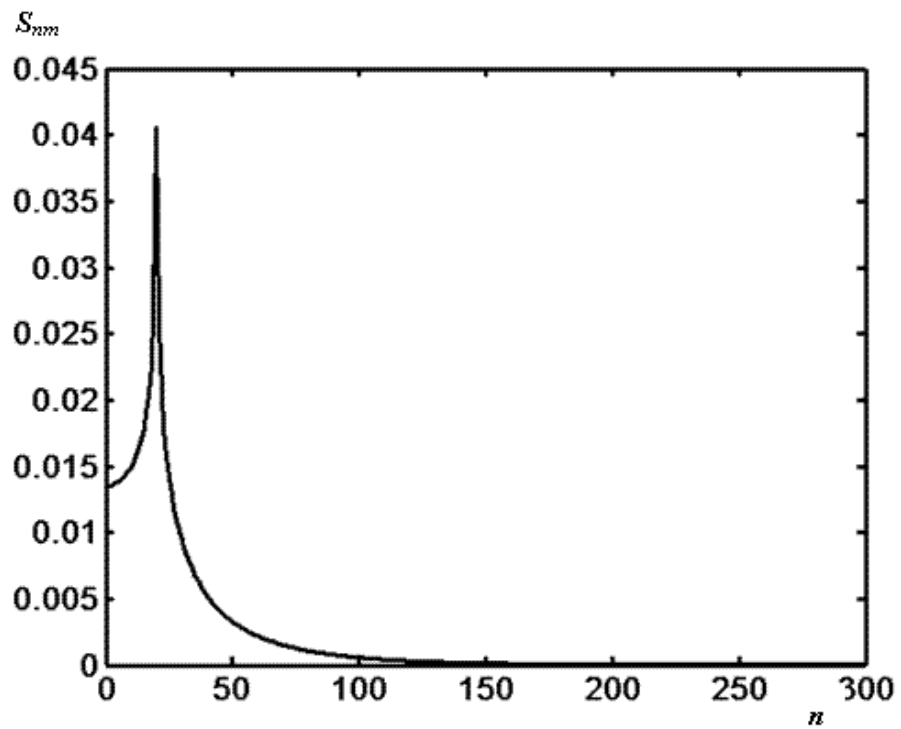

Fig. 2. Probability of the e-h pair generation in cell $\mathrm{n}$ because of the reaction in cell $m=25$

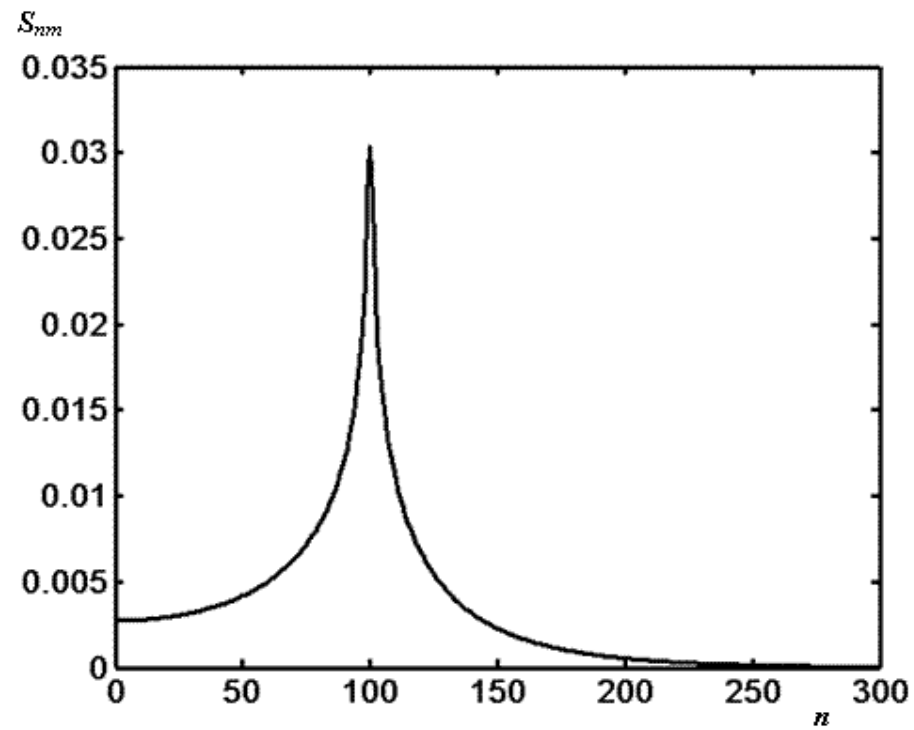

Fig. 3. Probability of the e-h pair generation in cell $\mathrm{n}$ because of the reaction in cell $\mathrm{m}=100$

in the area next to the surface (distance between the cell and the surface is smaller than $r_{o}$ ) reflected energy does not absorbed significantly by the layer of the sample, so the energy of the secondary wave is bigger than the same value in case of the cells, which are far from the surface. This is the case of the cells with numbers 1 : $\left(n_{i}-1\right)$ or $\left(n_{i}+1\right)$ : $n$. While moving to the centre of the crystal the curve becomes symmetrical. Maximal values among the elements of each line, as it was mentioned above, correspond to the probability of the generation in the same cell where the reaction takes place. The maximal values of the element $s_{i i}$ differ for the different lines (Fig. 3). Dependence of $s_{i i}$ on the number of the cell has several extremes. The maximal value corresponds to the crystal centre, because in that case $s_{i i}$ 
is calculated as a sum of probabilities of generation from all cells of the crystal and at the same time always contains the part, which considering the maximal contribution of the centre cell.

Ordinary differential system describing the process of the reaction with non-local development stage (1-6) was solved using the Runge-Kutta method of 1-5 order with time varied pitch. During the calculation of the kinetics the relative error does not exceed $10^{-12}$. Results of the simulation of the processes of the chain reaction initiation and development, initiated by the laser pulse with diameter $600 \mu \mathrm{m}$, presented on Fig. 4 and Fig. 5. Constants of the elementary stages, used to simulate the process, were estimated in works $[14,15,19]$. After the termination of the laser action concentration of reagent $\mathrm{A}$

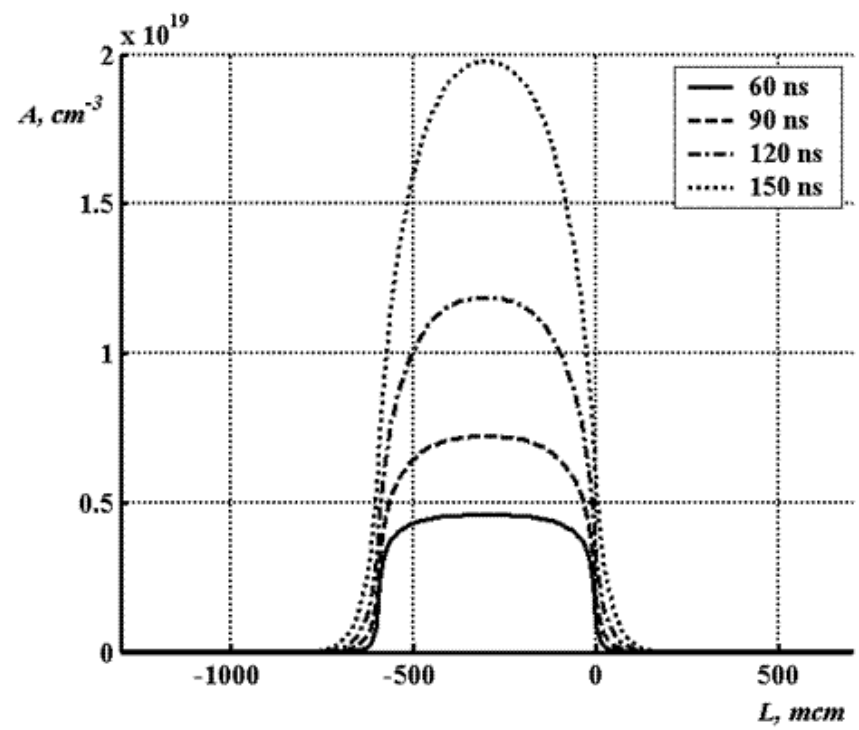

Fig. 4 Calculated distributions of A complexes in the crystal in 60,90,120,150 ns after the impulse termination

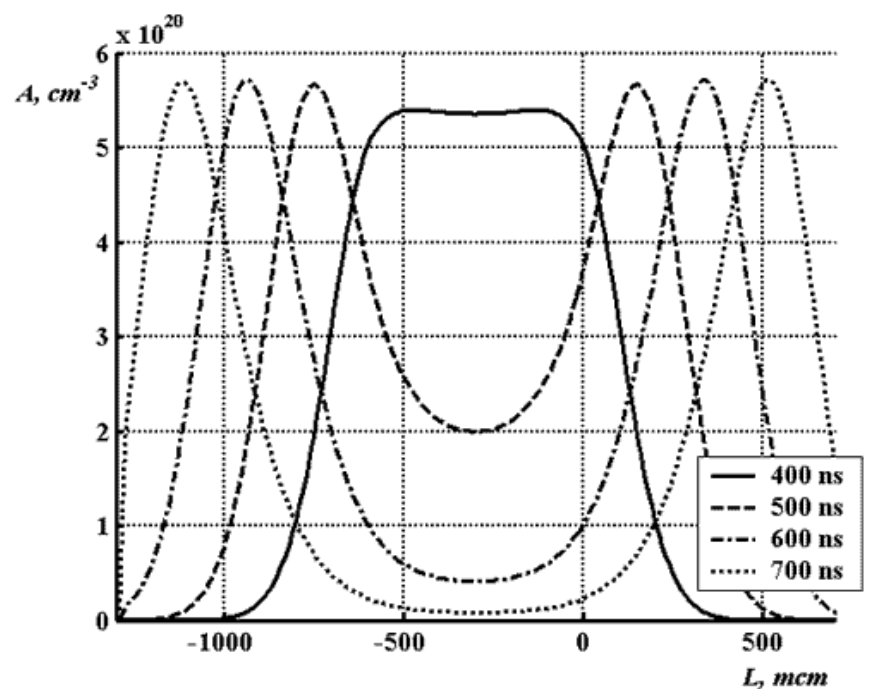

Fig. 5. Calculated distributions of A complexes in the crystal in $400,500,600,700$ ns after the impulse termination 
$\left(\mathrm{N}_{6}\right.$ complex) increases (Fig. 4), while the concentration of the chain carriers decreases (electron-hole pairs) - induction period of the reaction. A similar situation occurs for the homogeneous variant of the chain reaction [20]. Then the reagents' concentrations begin to increase outside the initiated zone at a distance about $100 \mu \mathrm{m}$. Estimation of the diffusion shift $\mathrm{D} \cdot \mathrm{t}\left(\mathrm{D}=0.25 \mathrm{~cm}^{2} / \mathrm{s}\right.$ diffusion coefficient [21], $\mathrm{t}$ - time of calculation) gives the value $\sim 1 \mu \mathrm{m}$. Hence, the main reason of the reaction initiation outside the irradiated zone is not a diffusion, but generation of the reagents due to the non-local character of the branching stage.

When the induction period is over the concentrations of the holes and complex A begin to grow in step both in the irradiated area and in the area, which was not initially acted by the laser pulse. Development of the chain reaction causes decomposition of the anion sublattice and degeneration of the chain reaction. But by this time concentrations of the reagents outside the radiated zone increase and become more than their critical values, and so two reaction fronts are formed. These fronts move towards the crystal edges (Fig. 5).

\section{Resume}

Non local behavior of the chain propagation stage causes significant active particles' redistribution. The concentrations of the active particles, generated by means of this way, decrease exponentially outside the reaction area. The active particles are generated symmetrically on all sides outside the reaction area. Optimal area of the crystal for the reaction to develop is the centre of the radiation zone.

This work was supported by Russian Foundation for Basic Research for the financial support (grant №14-03-00534 A) and Ministry of Education and Science of the Russian Federation (governmental project № 2014/64).

\section{References}

1. Kalenskii A.V., Kriger V.G., Zvekov A.A. et al The Microcenter Heat Explosion Model Modernization // Izvestia Vuzov Fizika. 2012. Vol. 55. No. 11-3. Pp. 62-66.

2. Zvekov A.A., Ananyeva M.V., Kalenskii A.V. et al Regularities of light diffusion in the compo site material pentaery thriol tetranitrate nickel // Nanosystems: Phys. Chem. Math. 2014. Vol. 5. No. 5. Pp. 685-691.

3. Ananyeva M.V., Kriger V.G., Kalensii A.V. et al Comparative analysis of energetic materials explosion chain and thermal mechanisms // Izvestia Vuzov Fizika. 2012. Vol. 55. No. 11-3. Pp. 13-17.

4. Kalenskii A.V., Ananyeva M.V. Spectral regularities of the critical energy density of the pentaerythriol tetranitrate -aluminium nanosystems initiated by the laser pulse // Nanosystems: Phys. Chem. Math. 2014. Vol. 5. No. 6. Pp. 803-810.

5. Patent 2538263 RU. Kriger V.G., Kalensii A.V., Ananyeva M.V., Zvekov A.A. Method of controlling the initiation threshold of optical detonator. Publ. Date 26.06.2013 (In Russ.)

6. Burkina R. S., Morozova E. Yu., Tsipilev V. P. Initiation of a Reactive Material by a Radiation Beam Absorbed by Optical Heterogeneities of the Material // Combustion, Explosion, and Shock Waves. 2011. Vol. 47, No. 5. Pp. 581-590.

$$
-187-
$$


7. Aduev B. P., Nurmukhametov D. R., Furega R. I. et al Explosive decomposition of petn with nanoaluminum additives under the influence of pulsed laser radiation at different wavelengths // Russian Journal of Physical Chemistry B. 2013. Vol. 7, No. 4. Pp. 453-456. DOI: 10.1134/ S199079311304012X

8. Kriger V. G., Kalenskii A. V., Zvekov A. A. et al Effect of laser radiation absorption effciency on the heating temperature of inclusions in transparent media // Combustion, Explosion, and Shock Waves. 2012. Vol. 48, No. 6. Pp. 705-708. DOI: 10.1134/s001050821206007x

9. Kriger V. G., Kalenskii A. V., Zvekov A. A. Determining the onset of mechanical failure of silver azide crystals initiated by laser pulse // Combustion, explosion, shocks waves. 2010. Vol. 46, No. 1. Pp. 60-63. DOI: 10.1007/s10573-010-0010-z

10. Aduev B.P., Anan'eva M. V., Zvekov A.A. et al Miro-hotspot Model for the Laser Initiation of explosive Decomposition of Energetic Materials with Melting Taken into Account // Combustion, Explosion, and Shock Waves. 2014. Vol. 50. No. 6. Pp. 704710. DOI 10.1134/S0010508214060112

11. Kriger V.G., Kalenskii A.V., Zvekov A.A. et al Heat-transfer processes upon laser heating of inert-matrix-hosted inclusions// Thermophysics and Aeromechanics. 2013. Vol. 20. No. 3. Pp. 367-374. DOI: $10.1134 / \mathrm{S} 0869864313030153$

12. Kriger V.G., Kalenskii A.V., Zvekov A.A. et al Determination of spatial characteristics of the chain reaction wave in silver azide// Russian Journal of Physical Chemistry B. 2014. Vol. 8. No. 4. Pp. 485-491. DOI: 10.1134/S1990793114040198

13. Kriger V.G., Kalenskii A.V., Zvekov A.A. et al Determining the width of the reaction wave front in the explosive decomposition of silver azide // Combustion, Explosion, and Shock Waves. 2012. Vol. 48, No. 4. Pp. 488-495. DOI: 10.1134/S0010508212040168

14. Kalenskii A. V., Anan'eva M. V., Kriger V.G. et al Rate constant of capture of electron charge carriers on a screened repulsive center // Russian Journal of Physical Chemistry B. 2014. Vol. 8, No. 2. Pp. 131-135. DOI: 10.1134/S1990793114020158

15. Kriger V. G., Kalensky A. V., Zvekov A. A. Relaxation of electronically excited products of solid-state reactions in the crystal lattice // Russian Journal of Physical Chemistry B. 2012. Vol. 48, No. 1. Pp. 15-18. DOI: 10.1134/S1990793112010101

16. Kriger V.G., Kalenskii A.V., Zvekov A.A., Tsipilev V.P. Explosive decomposition of silver azide single crystals for various diameters of the irradiated area //Combustion, Explosion, and Shock Waves. 2009. T. 45. № 6. C. 729-731. DOI: 10.1007/s10573-009-0090-9

17. Zvekov A. A., Kalenskii A. V., Nikitin A. P., Aduev B. P. Radiance distribution simulation in a transparent medium with fresnel boundaries containing aluminum nanoparticles // Computer Optics. 2014. Vol. 38, No. 4. Pp. 749-756.

18. Aduev B. P., Nurmukhametov D. R., Belokurov G. M. et al Integrating sphere study of the optical properties of aluminum nanoparticles in tetranitropentaerytrite // Technical Physics. 2014. Vol. 59, No. 9. Pp. 1387-1392. DOI 10.1134/S1063784214090023

19. Ananyeva M.V., Kalenskii A.V. The size effects and before-threshold mode of solid-state chain reaction // Journal of Siberian Federal University. Chemistry. 2014. T. 7. № 4. C. 470-479.

20. Kalenskii A.V., Zvekov A.A., Anan'eva M.V. et al Laser wavelength influence on the critical densty of initiation energy of energetic materials// Combustion, Explosion, and Shock Waves. 2014. Vol. 50. No. 3, Pp. 333-338. DOI: 10.1134/S0010508214030113 
21. Kriger V. G., Kalenskii A. V., Ananeva M. V., Borovikova A. P. Critical initiation-energy density as a function of single-crystal size in explosive decomposition of silver azide // Combustion, Explosion, and Shock Waves. 2008. Vol. 44. No. 2. Pp. 190-192. DOI: 10.1007/s10573-008-0025-x 